Conflict of Interest: The authors of this paper have no conflicts of interest, including specific financial interests, relationships, and/or affiliations relevant to the subject matter or materials included.

Financial Disclosure: The authors declared that this study received no financial support.

\section{References}

1. Singh A, Yong-Jie X. The cell killing mechanisms of hydroxyurea. Genes 2016;7:99-102.

2. Aste $N$, Fumo G, Contu F, Aste N, Biggio P. Nail pigmentation caused by hydroxyurea: report of 9 cases. J Am Acad Dermatol 2002;47:146-147.
3. Antonioli E, Guglielmelli P, Pieri L, Finazzi M, Rumi E, Matinelli V, Vianelli V, Randi ML, Bertozzi I, Stefano N, Za T, Rossi E, Ruggeri M, Elli E, Cacciola E, Pogliani E, Rodeghiero F, Baccarani M, Passamonti F, Finazzi G, Rambaldi A, Bosi A, Cazzola M, Barbui T, Vannuchi A. Hydroxyurea-related toxicity in 3,411 patients with $\mathrm{Ph}^{\prime}$-negative MPN. Am J Hematol 2012;87:552-554.

4. Mendonça R, Gueiros LA, Capellaro K, Pinheiro VR, Lopes MA. Oral lesions associated with hydroxyurea treatment. Indian J Dent Res 2011;22:869-870.

5. Kumar A, Kumar V, Singh J, Hooda A, Dutta S. Drug-induced discoloration of teeth: an updated review. Clin Pediatr 2012;51:181-185.

6. Ozyurt K, Baykan H, Ozturk P, Silay E. Case of longitudinal melanonychia secondary to hydroxyurea. UHOD 2013;23:53-54.

\title{
Rare Presentation of Herpes Virus Lesions in a Case of Acute Pre-B Lymphoblastic Leukemia
}

\author{
Akut Pre-B Lenfoblastik Lösemili Bir Olguda Herpes Virüs Lezyonlarının Nadir \\ Presentasyonu
}

(1) Eylem Kaymaz, (10 Zeliha Güzelküçük, (1) Melek Işık, (10 Neşe Yaralı

University of Health Sciences, Ankara Child Health and Diseases Hematology Oncology Training and Research Hospital, Clinic of Pediatrics, Ankara, Turkey

To the Editor,

A 6-year-old girl with the diagnosis of acute pre-B lymphoblastic leukemia had febrile neutropenia and pneumonia after induction chemotherapy. Though wide-spectrum antibiotics were started and then antifungal treatment was added, the fever could not be controlled. During this period, a small vesicle resembling herpes labialis developed at the edge of her lip and acyclovir was added. The patient's respiratory distress improved with combined antibacterial and antifungal therapy and saturation increased to normal levels after 1 week. During this period when the patient was afebrile, 3-5 vesicles were noted on her palm (Figure 1).

Herpes simplex virus (HSV) has two types, HSV-1 and HSV-2, and these viruses are members of the herpesviruses family. HSV can usually have lesions on different areas of body. Clinical presentations range from asymptomatic infection to mucocutaneous infections such as orolabial, ocular, genital herpes, herpetic whitlow, herpes gladiatorum, and eczema herpeticum as well as neonatal herpes, herpetic encephalitis, and fatal dissemination $[1,2]$. The diagnosis of HSV infection

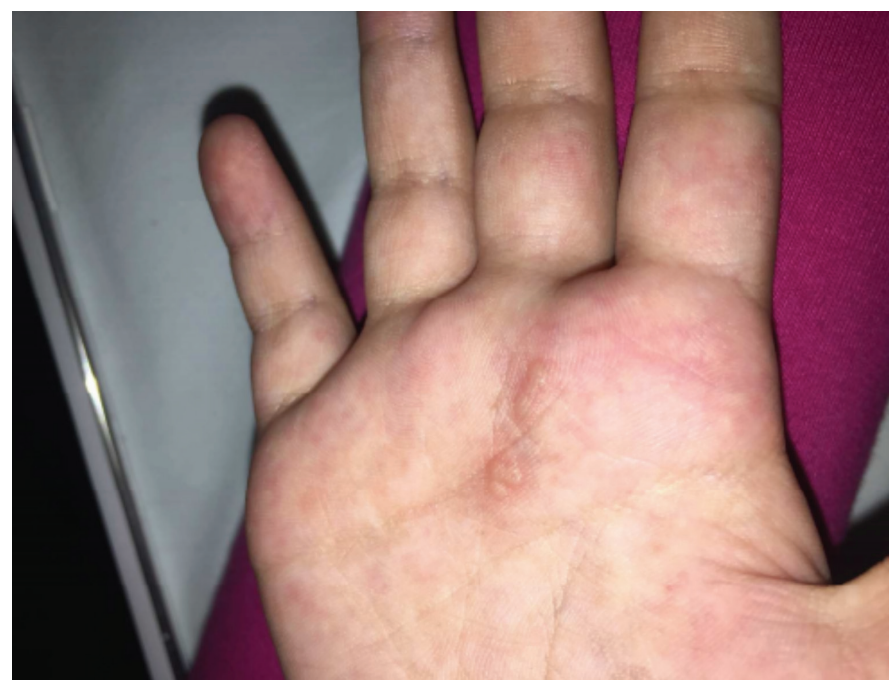

Figure 1. Vesicular lesions located on the hyperemic skin of the palm. 
can mostly be done with the clinical appearance of the lesions and the history of the patient. It mostly produces oral and perioral lesions but it may disseminate systematically and cause secondary bacterial and fungal infections [3]. In children, HSV infections on the hand most commonly occur on the fingers and thumb, called herpetic whitlow. This infection can be secondary to autoinoculation of the virus from a primary oral HSV infection such as gingivostomatitis or inoculation by a different person who bites or sucks on the finger $[4,5]$. The palmar area is involved less commonly and can be transmitted to others through contact with skin vesicles and also in patient skin-to-skin contact. In our patient, the palmar lesion was transmitted from her labial herpes.

Keywords: Herpes virus, Leukemia, Child

Anahtar Sözcükler: Herpes virüs, Lösemi, Çocuk

Informed Consent: It was obtained from parents or legal guardians before the patient's enrollment in the study.

\section{Authorship Contributions}

Concept: N.Y.; Design: Z.G., M.I.; Data Collection or Processing: N.Y., Z.G.; Literature Search: Z.G., E.K.; Writing: E.K., Z.G.
Conflict of Interest: The authors declare no potential conflicts of interest with respect to the research, authorship, and/or publication of this article.

Financial Disclosure: The authors declare that this study received no financial support.

\section{References}

1. Widener RW, Whitley RJ. Handbook of Clinical Neurology. Amsterdam, Alex Tselis \&t John Booss, 2014.

2. Fatahzadeh $M$, Schwartz R. Human herpes simplex virus infections: epidemiology, pathogenesis, symptomatology, diagnosis, and management. J Am Acad Dermatol 2007;57:737-763.

3. Epstein J, Scully C. Herpes simplex virus in immunocompromised patients: growing evidence of drug resistance. Oral Surg Oral Med Oral Pathol 1991;72:47-50.

4. Walker LG, Simmons BP, Lovallo JL. Pediatric herpetic hand infections. J Hand Surg Am 1990;15:176-180.

5. Gill M, Arlette J, Buchan K. Herpes simplex virus infection of the hand. J Am Acad Dermatol 1990;22:111-116.

๑Copyright 2020 by Turkish Society of Hematology

Turkish Journal of Hematology, Published by Galenos Publishing House

Address for Correspondence/Yazışma Adresi: Zeliha Güzelküçük, M.D., University of Health Sciences,

Ankara Child Health and Diseases Hematology Oncology Training and Research Hospital, Clinic of Pediatrics,

Ankara, Turkey

Phone : +312 5969600

E-mail : drguzelkucuk@hotmail.com ORCID: orcid.org/0000-0003-1462-6867
Received/Geliş tarihi: October 24, 2018 Accepted/Kabul tarihi: November 23, 2018

DOI: 10.4274/tjh.galenos.2018.2018.0372 